\title{
An activity for gifted and talented students to learn the concept of keystone species
}

\author{
Gökşen ÜÇÜNCÜ* \\ National Ministry of Education, Istanbul ORCID: 0000-0001-8107-229X \\ Ferhat KARAKAYA \\ Yozgat Bozok University, Yozgat ORCID: 0000-0001-5448-2226
}

\section{Mehmet YILMAZ}

Gazi University, Gazi Education Faculty, Maths and Science Education Department, Biology Education, Ankara ORCID: 0000-0001-6700-6579

\begin{tabular}{|c|c|}
\hline Article hist & \multirow{6}{*}{$\begin{array}{l}\text { In this study, it is aimed to design an analogy-oriented activity to be used } \\
\text { in teaching the concept of keystone species to students. The study was } \\
\text { carried out with } 25 \text { gifted and talented students aged between } 10 \text { and } 14 \\
\text { who were registered to the Science and Art Centers around in Turkey ( } \\
\text { Istanbul, Izmir, Ankara, Antalya, Mugla, Manisa, Balikesir, Kayseri). } \\
\text { This research was intended for these students to associate the concept of } \\
\text { keystone species in environmental education using creative thinking } \\
\text { skills with the help of a model. The study can be described as a special } \\
\text { case study aiming to produce conclusions about a situation. With the } \\
\text { designed activity, it was also aimed to contribute to the learning of the } \\
\text { concept of keystone species in a meaningful fashion through carrying out } \\
\text { analogy work with the keystone in architectural structures. The results of } \\
\text { the activity were evaluated with open-ended questions that the students } \\
\text { answered to. It was observed that the students could explain the concept } \\
\text { of keystone species by associating it with the keystone used in } \\
\text { architecture in line with the definition of the concept. Considering the } \\
\text { results of this study, it can be said that gifted and talented students } \\
\text { generated an analogy for the keystone species. The designed activity was } \\
\text { evaluated at the end of the study in environmental education courses in } \\
\text { terms of its applicability. It was found that the developed activity was } \\
\text { applicable as it enabled the active participation of the students. }\end{array}$} \\
\hline & \\
\hline $\begin{array}{l}\text { Received in revised form: } \\
02.03 .2020\end{array}$ & \\
\hline $\begin{array}{l}\text { Accepted: } \\
8.03 .2020\end{array}$ & \\
\hline Key words: & \\
\hline & \\
\hline
\end{tabular}

\section{Introduction}

In today's world where the advances in science and technology are on drastic increase, countries need a fair number of strategic planning attempts to keep pace with this rapid development. At the basis of this need, there are gifted and talented individuals and their education (Esen, 2011). Individuals with special abilities differ from their peers in terms of cognitive perception speed, in-depth learning and interests (Csikszentmihalyi \& Robinson, 
1986; Renzulli \& Reis, 1985). Thereupon, gifted and talented students should be supported outside the existing curriculum. Being affiliated to the Ministry of Education, the Science and Art Centers have been serving since 2006 in order to contribute to the education of gifted and talented students in Turkey. In fact, gifted and talented students are supported by these centers according to their interests and skills in addition to the school programs they participate in formal education (MOE, Science and Art Centers Directive, 2006). Sahin and Levent (2015) determined that the classroom and science teachers in the study groups do not have sufficient knowledge about the gifted and talented students. Therefore, they stated that it is highly important for teachers working with gifted and talented students to receive in-service training on the teaching strategies they will apply for these students. Similarly, Colangelo (2018) emphasizes that teachers working with gifted and talented students gain this specific type of knowledge through experience and must develop themselves professionally.

There is an increasing need for teachers who are to have a major impact on the development and the progress of the countries (Karakaya, Unal, Cimen \& Yilmaz, 2018), and who will be the ones to create suitable learning environments for gifted and talented students. The activities that pave the way for the development of in-depth understanding, problem solving and critical as well as creative thinking skills of gifted and talented individuals are of crucial importance. Science courses indeed play a critical role in acquiring these skills and learning abstract concepts effectively (Cayci, 2007; Clevland, Olimpo \& Peters, 2017; Costu, Karatas \& Ayas, 2003; Gunes, Dilek, Demir, Hoplan \& Calikoglu, 2010; Ross, Tronson \& Ritchie, $2015)$ bearing in mind that one of the aims of science courses which include abstract concepts (Gunbatar \& Sari, 2002) is to provide meaningful learning to students without memorization of these concepts (Gunes et al., 2010).

The concepts that form the basis of knowledge are defined as the abstract and general design of an object or idea in the mind (TDK-Turkish Language Association, 2011). From childhood, people begin to learn the concepts around them and create designs about these concepts in their minds. As a matter of fact, organizing and structuring new concepts to existing concepts in their cognitive structures is a lifelong process (Kaptan, 1999). It is seen that two methods are mainly resorted to in the literature of concept teaching (Ayas, Cepni, Johnson \& Turgut, 1997; Kaptan, 1999). These are the traditional (through presentation) and modern (through invention) concept teachings. In the traditional approach, the following stages are discussed: 1-Giving the word concept, 2- Giving the definition of the concept, 3- Giving the features that define and distinguish the concept, 4- Giving examples about the concept (Cayci, 2007). However, it is suggested that this method is not effective enough to learn the concepts (Canpolat \& Pinarbasi, 2002; Ross et al., 2005) fully and as desired. In the novel approach, concept teaching is handled with an inductive stage. Generalization starts from models related to concepts (Costu, Karatas \& Ayas, 2003). This method supports the purposeful and meaningful learning of the concept (Cayci, 2007).

In the relevant process, the student must learn a new concept by associating it with his/her previous knowledge. For this, it is very important that teachers provide learning environments and teaching materials that will give students the opportunity to test the experiences in which they can create their own knowledge (Costu et al., 2003). For this reason, teachers are required to follow the effective teaching methods and ensure practice for concept learning in their classrooms (Gunes et al., 2010). One of the methods suggested to provide meaningful and in-depth learning in concept learning is to teach concepts through analogy (Ross \& Tronson, 2004). Analogy is defined as an effective cognitive mechanism used to learn new concepts by making inferences (Gentner \& Holyoak, 1997). Analogies constitute effective 
learning and teaching tools that assist students in questioning what they know and creating new knowledge (Duit, 1991). Harrison (1992) revealed that as a result of the application of analogy teaching model in science courses, the eighth and tenth graders comprehended the science concepts easier which are normally learnt with difficulty. Similarly, Glynn, Law, Gibson \& Hawkins (1996) found that analogies made it easier for seventh-grade students to understand the notion of electricity. Pittman (1999) argues that the use of analogies for the subject of protein synthesis in a Biology class enabled students to learn the subject more easily. Bryce and Mac Millan (2005) pinpointed that teaching the subject of action-reaction forces with the analogy approach is more effective in developing students' cognitive skills aiding the realization of a conceptual change. Chiu and Lin (2005) found that analogy applications in the electrical unit in the fourth grade were effective not only for students to learn concepts but also to correct their misconceptions. In this study, it is aimed to develop an activity for gifted and talented students to learn the concept of keystone, which is one of the concepts within the scope of environmental education, by associating it with the keystone in architectural designs. This association is discussed with an analogical approach. The keystone is a wedge-shaped stone which is at the top of an arch and is vital to keep the structure together, and when it is removed, the entire arch collapses (Withgott \& Brennan, 2008). The term of keystone species is derived from a wedge-shaped stone which is located at top of such an arch and ties the other parts together. A keystone species occupies an ecological niche that holds the entire community in place. The keystone species that play a greater role than others in communities is the species with a high impact on the community (Simon, Dickey, Hogan \& Reece, 2017).

Ecologists define keystone species as the ones that can greatly affect the community structure, although they are few in the community. A keystone species plays a critical role in determining the species distribution of the community (Sadava, Hillis, Heller \& Berenbaum, 2017; Cunningham and Cunningham, 2017; Russel, Hertz \& McMillan, 2011). The extinction of such species or group of species from the ecosystem leads to significant changes and even to destruction of the community structure and ecosystem functions (Odum \& Barrett, 2008; Johnson, 2018). As has been mentioned earlier, keystone species are not always abundant in the community. They provide strong control over the community; and they do not do so with their numerical superiority yet with their important ecological roles or niches (Reece, Urry, Cain, Wasserman, Minorsky \& Jackson, 2013; Smith \& Smith, 2009). Keystone species influence both the richness of richness and the number of trophic levels in a community (Sadava et al., 2014). Nutritional activities of a few keystone species can control the structure of communities. For example, sea otters, which have a large ecological impact on the community they live on because of feeding with benthic invertebrates, are generally called keystone species by ecologists, although their population density is low and they are one of the smallest marine mammals (Molles, 2016).

Learning the concept of keystone species is key to understanding the ecological balance in populations. Hence it is one of the concepts that should be considered within the scope of environmental education. In order for the gifted and talented students to understand the structure of the ecosystem in depth, examples such as the concept of keystone species should be referred to. For this purpose, it is fundamental for teachers to address specific ecologyspecific examples, such as the concept of keystone species, within the learning designs appropriate to the individual characteristics of these students. Thusly in the curricula available, it is necessary to develop examples of similar activities and materials (Costu, Karatas \& Ayas, 2003) for teachers to make use of for their students. In this study, it is aimed to design an activity that can be implemented within the scope of environmental education by 
teachers and researchers working with gifted and talented students.

\section{Method}

In this research, an analogy-oriented activity to teach keystone species, which is an important concept in environmental education, is discussed in detail and the application results of this activity are evaluated. With this aspect of it, the study can be described as a special case study aiming to produce conclusions about a situation (Yildirim \& Simsek, 2011).

\section{Study Group}

The study group consisted of 25 gifted and talented students who received training at BILSEM (Science and Art Center) institutions and who were between the ages of 10-14 years. BILSEM students are assesed by annual test which evaluates students' cognitive, art and music talents. In this study group all students are chosen by their cognitive talents. 11 of the participants were female and 14 were male. The mean age is 11.92 years. Descriptive characteristics of study group are shown in Table 1.

Table 1. Descriptive Characteristics of The Study Group

\begin{tabular}{llllllll}
\hline No & Gender & Age & $\begin{array}{l}\text { Registered } \\
\text { BILSEM }\end{array}$ & No & Gender & Age & Registered BILSEM \\
\hline 1 & $\mathrm{~F}$ & 11 & Ankara & 15 & $\mathrm{~F}$ & 12 & Izmir \\
2 & $\mathrm{M}$ & 13 & Ankara & 16 & $\mathrm{M}$ & 12 & Manisa \\
3 & $\mathrm{M}$ & 12 & Ankara & 17 & $\mathrm{M}$ & 13 & Mugla \\
4 & $\mathrm{M}$ & 14 & Antalya & 18 & $\mathrm{~F}$ & 13 & Mugla \\
5 & $\mathrm{M}$ & 13 & Burdur & 19 & $\mathrm{~F}$ & 10 & Mugla \\
6 & $\mathrm{M}$ & 12 & Istanbul & 20 & $\mathrm{~F}$ & 13 & Mugla \\
7 & $\mathrm{M}$ & 10 & Istanbul & 21 & $\mathrm{~F}$ & 13 & Mugla \\
8 & $\mathrm{M}$ & 10 & Istanbul & 22 & $\mathrm{~F}$ & 13 & Mugla \\
9 & $\mathrm{~F}$ & 10 & Istanbul & 23 & $\mathrm{~F}$ & 13 & Balikesir \\
10 & $\mathrm{M}$ & 14 & Istanbul & 24 & $\mathrm{M}$ & 10 & Kayseri \\
11 & $\mathrm{M}$ & 10 & Istanbul & 25 & $\mathrm{~F}$ & 10 & Mugla \\
12 & $\mathrm{~F}$ & 14 & Izmir & & & & \\
13 & $\mathrm{M}$ & 11 & Izmir & & & & \\
14 & $\mathrm{M}$ & 11 & Izmir & & & & \\
\hline
\end{tabular}

F: Female students, M: Male students

\section{Design and Implementation of the Activity}

\section{Preliminary Preparation}

Various arch structure models were designed and computer drawings were made by the researchers. The drawing shown in Figure-1 was taken to the carpenter's workshop and its mould was made. Thus, the pieces of wood which represent the stones in the arch (a and $b$ ) were obtained (Picture-1). It was considered the pieces would be used in the group work by the students, so identical parts were created in equal numbers for six groups. 


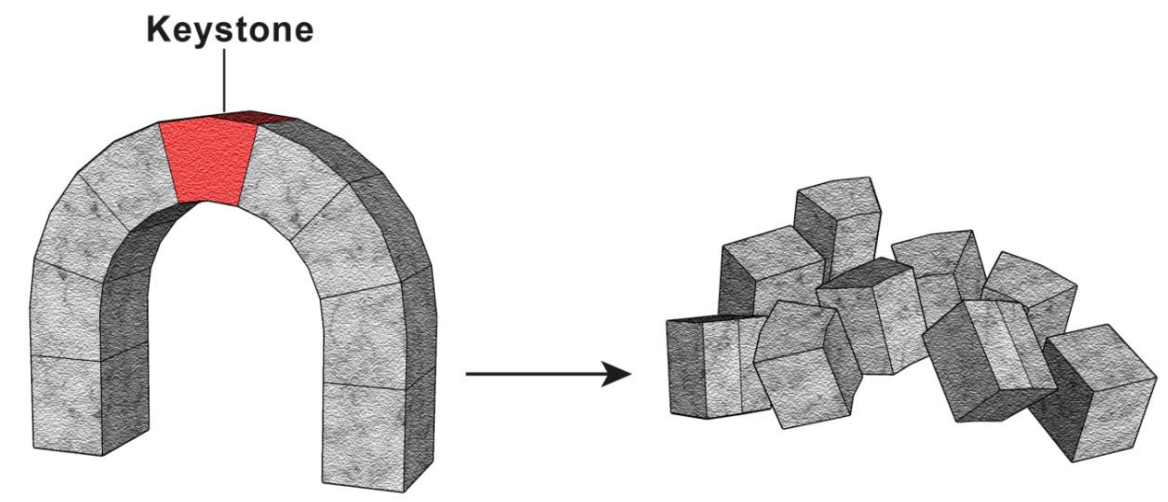

Figure-1: Drawing made for keystone

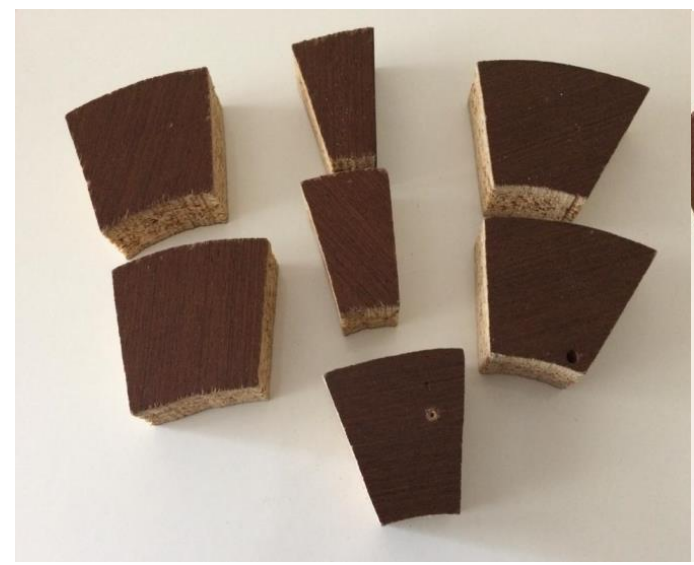

(a)

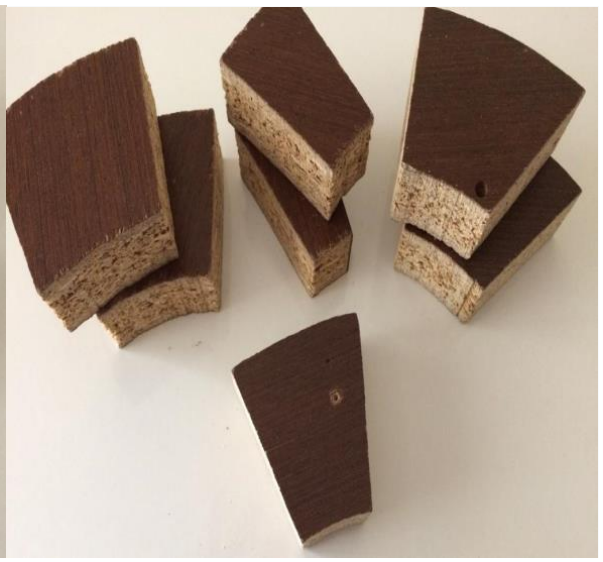

(b)

Picture-1-a.b.: Parts made by carpenter

\section{Implementation of the activity}

- Name of the activity: Keystone

- Method of the activity: Analogy

- Type of the activity: Group work

- Purpose of the activity: It is aimed that gifted and talented students learn the meaning of keystone by associating the keystone in architectural structures with the concept of keystone-one of the concepts in ecology.

- Activity time: $60 \mathrm{~min}$.

- Participants: Gifted and talented students who are aged between10-14 (a total of 25 gifted and talented students who are registered to BILSEM and continuing their education in this institution).

- Materials: 6 sets of wooden blocks in Picture 1

\section{Implementation Directive of the Activity}

a. Preparation

- Students are divided into 4-person groups.

- Students are first asked if they know the concept of keystone species. If they know, they are asked to explain this concept. 
- Students are given visuals containing examples of arch-shaped structures, which they also encounter in their daily lives.

- Students are asked to look carefully at the stones in these arch structures and tell which stone bears difference in relation to its appearance.

b. Implementation

- Wooden blocks consisting of nine pieces of various sizes are distributed to the groups.

- Groups are asked to build arch structures by using wooden pieces on their desks.

- There is no time limit for groups to design their arch structures.

- The groups completed their arch structures in a vertical position on the table. Photographs of these arch structures were taken (Figure-2 (a) and (b))

- Groups were allowed to build their arch structures in more than one way.

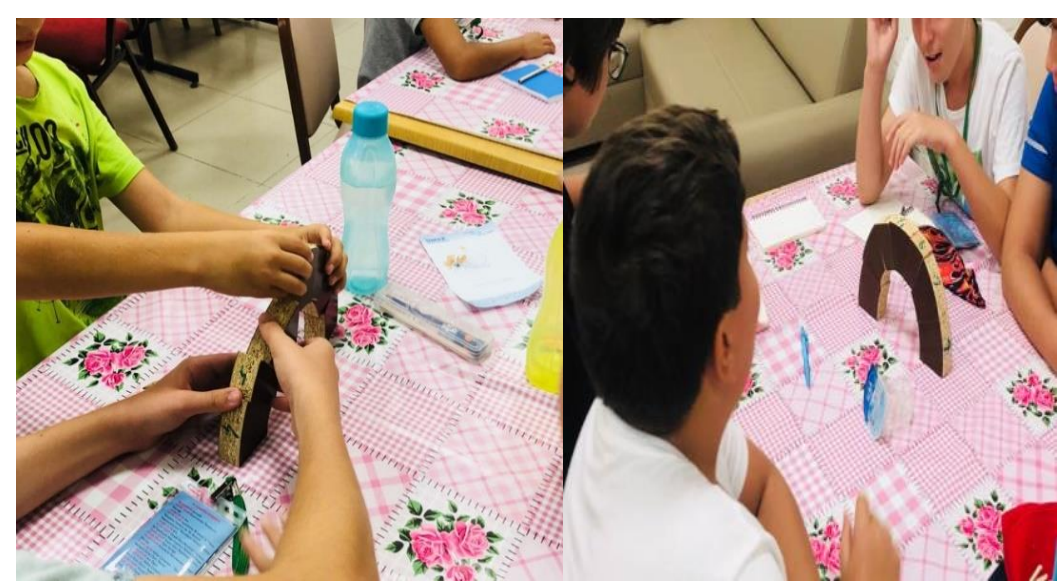

(a)

(b)

Picture 2- a. b.: Group work for arch building

c. Evaluation of Activity

- The groups were asked the questions of "What is the most different piece of wood that you used on your arch structures?" and "Which piece did you use the least?"

- After pointing to the piece of wood that connects the two side columns in the middle of the top, the groups were asked the question of "What is the function of this piece in the arch structure?"

- After each student was given the opportunity to give their answers, the question of "How would you like to name this piece of wood?" was asked.

- After the questions were answered, all students were told the following ecological story by using visuals.

- Ecological Story: "Scientists have conducted a controlled experiment for 10 years in a rocky tidal zone in western North America, examining the change in species richness. In the first case, they stated that there were 17-20 different species in the environment, including starfish, mussels, various algae and small crustaceans (control group). It is known that starfish feed themselves with mussels in this rocky area. In the second case, the small number of starfish was transferred from the rocky area to another area. After the starfish were taken away, mussels occupied the rocky area. Mussels quickly consumed algae and other invertebrates in the environment. Wherefore, species richness in the environment declined drastically and it was observed that it decreased to 1-2 species over the years" (Simon et al., 2017; Molles, 2016; Johnson, 2018; Sadava et al., 2014). 
- After listening and reviewing this ecological story, students were asked the question of "Which one do you think has the keystone function of the living creatures mentioned in this ecological story to be matched with the wooden pieces you have just put on your arch structure?"

- Each student was asked to write down his/her answers on the papers with her/his reasons and these papers were collected.

- The students were asked to tell stories about natural habitats in the group if they knew any stories similar to the aforementioned ecological story.

\section{Findings}

This section presents the findings of the activity. First of all, the students were asked whether they knew the concept of keystone species with a view to checking their previous knowledge. The answers given by the students to this question are given in Table 2 .

Table 2. Students' previous knowledge about the concept of keystone species

\begin{tabular}{lccl}
\hline Codes & $\mathrm{f}$ & $\%$ & Sample of student opinions \\
\hline $\begin{array}{l}\text { It's an important } \\
\text { concept. }\end{array}$ & 10 & 40 & $\begin{array}{l}\text { S-9: When I say the key, I consider something } \\
\text { important } \\
\text { S-17: I don't know, but it's like something important }\end{array}$ \\
\hline I don't know. & 15 & 60 & $\begin{array}{l}\text { S-12: I don't know. } \\
\text { S-15: I don't know because I haven't learnt it before. }\end{array}$ \\
\hline
\end{tabular}

S: Student participating in the study

When the data in Table 2 is examined, $40 \%$ ( $\mathrm{f}=10$ ) of the students participating in the research articulated that the keystone species is an important concept and 60\% ( $\mathrm{f}=15$ ) announced that they did not know this concept. In the evaluation activities, the students were first asked the question of "What is the most different piece of wood in the arch structures you have built?" In the activity, which was designated as group work, certain students acted as the reporters of the pertinent groups. The data obtained are given in Table 3.

Table 3. Findings for the most different piece of wood

\begin{tabular}{|c|c|c|c|}
\hline Codes & $\mathrm{f}$ & $\%$ & Sample of student opinions \\
\hline $\begin{array}{l}\text { Piece placed in the } \\
\text { middle of the top }\end{array}$ & 23 & 92 & $\begin{array}{l}\text { S-1: The balancing piece we put in the middle of the } \\
\text { top } \\
\text { S-2: The piece we put at top of the arch. } \\
\text { S-3: At the top } \\
\text { S-4: At the top } \\
\text { S-6: In middle of the top of the arch } \\
\text { S-11: The piece at the top of the arch. } \\
\text { S-12: The last triangular piece we put } \\
\text { S-22: The piece we placed in the middle of the top } \\
\text { of the arch }\end{array}$ \\
\hline $\begin{array}{l}\text { First piece at the } \\
\text { bottom }\end{array}$ & 2 & 8 & $\begin{array}{l}\text { S-9: The first piece is different from the others } \\
\text { S-25: The part at the bottom is different }\end{array}$ \\
\hline
\end{tabular}

S: Student participating in the study

When the data in Table 3 is analyzed, 92\% ( $\mathrm{f}=23$ ) of the students participating in the research uttered that the related piece is the one placed in the middle of the top and $8 \%(f=2)$ 
shared that it is the first piece placed at the bottom, whose answer was different from the others. In the research, the students were asked the question of "What is the structure and function of this different part in the arch?" and the data obtained are given in Table 4.

Table 4. Findings on the structure and function of the most different part of the vault

\begin{tabular}{|c|c|c|c|}
\hline Codes & f & $\%$ & Sample of student opinions \\
\hline \multirow{5}{*}{$\begin{array}{l}\text { The piece } \\
\text { keeps the arch } \\
\text { in balance }\end{array}$} & \multirow{5}{*}{25} & \multirow{5}{*}{100} & $\begin{array}{l}\text { S-9: The piece we put at the top of the arch. Because when we } \\
\text { pulled this piece out, the arch was collapsed. }\end{array}$ \\
\hline & & & $\begin{array}{l}\text { S-14: The piece at the top. Because without that piece, the arch } \\
\text { cannot stand in balance. }\end{array}$ \\
\hline & & & S-19: To have an arch, you need to tie it together at the top. \\
\hline & & & $\begin{array}{l}\text { Some of the doors and bridges used to be built in this way in } \\
\text { the past. }\end{array}$ \\
\hline & & & $\begin{array}{l}\text { S-20: The different piece we last placed allows the arch to be } \\
\text { tied together. }\end{array}$ \\
\hline
\end{tabular}

S: Student participating in the study

When the data in Table 4 is reviewed, it is observed that $100 \%$ ( $f=25$ ) of the students participating in the research stated that the most different piece was the one which had a function of keeping the arch in balance. In the research, the students were asked the question of "How would you name this different piece of the arch?" and the data obtained are given in Table 5.

Table 5. Finding the most different piece of the arch

\begin{tabular}{llll} 
Codes & f & $\%$ & Sample of student opinions \\
\hline & & S-19: To have an arch, you need to tie it together at the top.
\end{tabular}
Some of the doors and bridges used to be built in this way in the past. The piece we placed in the middle of the top is called the keystone.

Keystone $\quad 23 \quad 92 \quad$ S-20: What I understand from the keystone is that it is the piece that keeps our arch in balance. In our model, I think the piece we put at the top is the keystone.

S-23: I think the piece at the top that keeps the arch in balance is the keystone. Because when that stone is pulled out, the arch collapsed.

S-16: I'm indecisive, one of the pieces is a little bit different, Undecided 28 but the others are not exactly the same, two of them seem the same, but the other two are different.

S-13: They all look different to me.

S: Student participating in the study

When the data in Table 5 is inspected, it is seen that $92 \%$ ( $\mathrm{f}=23$ ) of the students participating in the study named the most different piece of the arch as keystone, while $8 \%(f=2)$ stated that they were indecisive. In the research, the students were asked the question of "Which one do you think has the keystone function of the living creatures mentioned in this ecological story to be matched with the wooden pieces you have just put on your arch structure?" and the findings are given in Table 6. 
Table 6. Keystone findings in the ecological story

\begin{tabular}{|c|c|c|c|}
\hline Codes & $\mathrm{f}$ & $\%$ & Sample of student opinions \\
\hline Starfish & 25 & 100 & $\begin{array}{l}\text { S-4: The balance was disrupted when the starfish was taken away } \\
\text { S-11: The species richness in the environment decreased when the } \\
\text { starfish was taken away } \\
\text { S-17: The keystone serves to balance things. Like the starfish in } \\
\text { the story. } \\
\text { S-18: There is no balance without it. The starfish is a balancing } \\
\text { creature. } \\
\text { S-20: The starfish is also a keystone because it balances the } \\
\text { number of mussels and algae. } \\
\text { S-23: Starfish is the keystone species. Because when the keystone } \\
\text { species are taken away from the nature, there is a decrease in } \\
\text { species and the balance is disrupted. }\end{array}$ \\
\hline
\end{tabular}

When the data in Table 6 is scrutinized, it is seen that $100 \%$ ( $\mathrm{f}=25$ ) of the students who participated in the study stated that the starfish among the living creatures in the ecological story is the keystone.

\section{Discussion and Results}

In this study, it is aimed to design an analogy-oriented activity to be used in the teaching of the concept of keystone species to students. To that end, the activity prepared by the researchers was executed for the gifted and talented students. In this research, the students were asked about their previous knowledge about keystone species. It was determined that students do not know the scientific definition of this concept but have the idea that it is an important concept by making some inferences in light of the connotations of the very word. Individuals utilize analogies to define the characteristics of a concept that they do not know through a concept they do know (Paatz, Ryder, Schwedes \& Scott, 2004; Yenice, Tunc \& Yavasoglu, 2018). Analogies help students to embody abstract concepts and accelerate the learning process subsequently adding onto persistence (Dincer, 2011; Yenice et al., 2018). In this study, it can be reported that gifted and talented students generated an analogy for the keystone species. The students interpreted the keystone species as the species that provides protection of the natural environment with respect to the protection feature of the concept of keystone. When the literature was checked, numerous studies with metaphors and analogies for animals in the nature protection category were identified (Akgun, Duruk \& Gulmez Gungormez, 2016; Guven, 2014; Dogan, 2017). For instance, in a study conducted by Dogan (2017), it was determined that the secondary school students used a metaphor for the need of protecting the environment. These results support the findings of the study.

The aim of the study was to make an analogical relationship with the keystone in architectural designs and to contribute to the learning of the concept of keystone in a meaningful way. The applications included in the activity were carried out step by step with gifted and talented students. When the findings of the research were studied, it was found out that the gifted and talented students defined the wooden piece placed in the middle of the top as the most different piece and the piece that keeps the arch in balance. The students named this piece as the necessary "keystone" to keep the arch in balance. In the ecological story, the students stated that the starfish is the keystone species since it causes the balance to be disrupted when removed from the environment. Students' learning the concepts by establishing relationships rather than memorizing them and their producing new information are the ideals of the 
education system (Tatar \& Kuru, 2006). It would be fair to underpin that the use of analogies in teaching specific concepts increases the quality of learning of students (Demirci Guler, 2007). In this context, it can be declared that the activity designed in the research is an analogy that helps students to explain the concept of keystone species relating it to the keystone used in architecture, through the definition of the concept. When the literature on the subject is examined, it is seen that there is a body of research on the use of analogy in the teaching process (Akamca \& Hamurcu, 2009; Crain \& Hale, 2019; Celik, Kirindi \& Kotaman, 2016; Han \& Kim, 2018; Hidir \& Korhasan, 2018; Oren \& Ates, 2018) and guiding teaching materials (Bakirci \& Calik, 2013). For example, in the study conducted by Akamca and Hamurcu (2009), it was determined that science and technology education supported by analogies, concept caricatures and prediction-observation-explanation techniques contributed positively to the academic achievement of 5th grade students. In the study conducted by Bakirci and Calik (2013), it was determined that the guiding material developed for 8th grade students was effective in realizing conceptual change and arriving at alternative concepts of adaptation and natural selection.

Hidir and Korhasan (2018) express both faculty members and teachers had the opinion that the use of analogies in science education fostered learners' academic achievement. As a result of the research conducted by Oren and Ates (2018), it was figured out that micro teaching method using analogy increased the conceptual understanding of prospective teachers. Crain and Hale (2019), on the other hand, performed pancakes activity with high school students to help them to understand the natural selection theory. It was found that the students associated the crepe layers with the changes in the populations in the natural selection process and the theory was understood (Crain \& Hale, 2019). Celik et al. (2016), noted that computer-assisted analogy method was effective on 7th grade students' academic achievement and their knowledge retention while the 'Matter and its properties' unit was concentrated upon. Performing analogy-oriented activities in education is especially effective in stimulating the imagination of secondary school students and allowing the concepts to become more permanent (Ekici, Ekici \& Aydin, 2007). Analogy is also a technique that enables students to use their existing knowledge. (Crain \& Hale, 2019). Hence it is essential to make use of analogy technique to increase students' academic success and teach them scientific knowledge (Walker, Wassemberg, Franta \& Cotner, 2017)._In addition to that, the activities prepared with the analogy model form the infrastructure of the education system assuring that students gain skills and facilitating the formation of models of other sort (Aragón, Oliva \& Navarrete, 2014). In the study conducted by Han and Kim (2018), it was aimed to see how primary school students cope with the human respiratory system with analogy-oriented activities. In this research it was put forward that analogy-oriented activities could be the source of students' reasoning and other models to be created. These results support the overall findings of the study and show that the developed keystone species activity may be a resource for teaching ecosystem concepts.

Considering the results of this study, the following are suggested:

- The teaching of the concept of "keystone species" in which students participate actively and were engaged can also be implemented with groups of students at other levels of education.

- Similar applications can be possible for the teaching of other subjects of ecology. 
- Prior to starting the teaching of such a concept, the process should be planned meticulously and a detailed literature review should be conducted to establish a sound scientific foundation.

- This study and similar studies should be carried out in particular with prospective teachers so as to raise awareness of them of such uses in the classroom.

\section{References}

Akamca, G.O., \& Hamurcu, H. (2009). Science and technology education based on analogies, concept cartoons and predict-observe-explain techniques. Education Sciences, 4(4), 1186-1206.

Akgün, A., Duruk, Ü., \& Gülmez Güngörmez, H. (2016). Secondary school students' metaphors related to environmental education. Dicle University Journal of Ziya Gökalp Education Faculty, 28, 215-224.

Aragón, M., Oliva, J., \& Navarrete, A. (2014). Contribution of learning through analogies to the construction to of secondary education pupils' verbal discourse about chemical change. International Journal of Science Education, 36(12), 1960-1984.

Ayas, A., Çepni, S., Johnson, D., \& Turgut, M.F. (1997). Kimya Öğretimi, Öğretmen Ĕ̈itimi Dizisi[Chemistry Teaching, Teacher Education Series]. Ankara: YÖK / DB National Education Development Project Publications.

Bakırcı, H., \& Çalık, M. (2013). Effect of guide materials developed in "adaptation and natural selection" subject on remedying grade 8 student's alternative conceptions. Education and Science, 38(168), 215-229.

Bryce, T., \& Mac Millan, K. (2005). Encouraging conceptual change: the use of bridging analogies in the teaching of action-reaction forces and 'at rest' condition in physics. International Journal of Science Education, 27(6), 737-763.

Canpolat, N., \& Pınarbaşı, T. (2002). Conceptual change approache in science education-I: theoretical basis. Kastamonu Education Journal, 10(1), 59-66.

Chiu, M., \& Lin, J. (2005). Promoting fourth graders' conceptual change of their understanding of current via multiole analogies. Journal of Research in Science Teaching, 42(4), 429-464.

Cleveland, L.M., Olimpo, J.T., \& DeChenne- Peters, S.E. (2017). Investigating the relationship between instructors' use of active-learning strategies and students' conceptual understanding and affective changes in introductory biology: a comparsion of two active- learning environments. CBE-Life Sciences Education, 16(19), 1-10.

Colengelo, N. (2018). Gifted education to honors education: a curious history, a vibrant future. Journal of The National Collegiate Honors Council-Online Archive. 583, 3-7.

Coştu, B., Karataş, Ö.F., \& Ayas, A. (2003). Kavram öğretiminde çalışma yapraklarının kullanılmas1 [Using worksheets in teaching concept]. Pamukkale University Journal of Education Faculty, 2(14), 33-48.

Crain, D. A., \& Hale, M. (2019). Pancake evolution: a novel \& engaging illustration of natural selection. The American Biology Teacher, 81(2), 110-114.

Csikszentmihalyi, M. \& Robinson, R. E. (1986). Culture, time and the development of talent. In R.J. Sternberg, \& J.E. Davidson (Eds.), Conceptions of giftedness. New York: Cambridge University Press.

Cunningham, W.P., \& Cunningham, M.A. (2017). Environmental Science: A Global Concern. USA: McGraw-Hill Education

Çaycı, B. (2007). The effect of conceptual change texts on the concept learning. Journal of Gazi Education Faculty, 27(1), 87-102. 
Çelik, H., Kırınd1, T., \& Kotaman, Y.A (2016). The effect on learning outcomes of the computer based analogy used in science teaching. Journal of Turkish Science Education, 13(2), 3-27.

Demirci Güler, M.P. (2007). Fen ögrretiminde kullanılan analojiler, analoji kullanımının ögrenci başarısı, tutumu ve bilginin kalıcılı̆̆ına etkisinin araştırılması [Analogies used in science teaching, the investigation of effect of analogy on students achievement, attitude and knowledge retention]. (Unpublished Doctoral Thesis), Gazi University, Institute of Educational Sciences, Ankara.

Dinçer, S. (2011). Exploring the impacts of the analogies on computer hardware. The Turkish Online Journal of Educational Technology, 10(2), 113-121.

Doğan, Y. (2017). Middle school students' intuitive perceptions related to concept of the environment: a metaphor analysis. Journal of Kırşehir Education Faculty (KEFAD), 18(1), 721-740.

Duit, R. (1991). On the role of analogies and metaphors in learning science. Science education, 75(6), 649-672.

Ekici, E., Ekici, F. \& Aydın, F. (2007). Preservice science teachers' views on usability of analoiies in science courses and their examples. Journal of Kırşehir Education Faculty (KEFAD), 8(1), 95-113.

Esen, T. (2011). Üstün yetenekli ögrrencilerin çevreye yönelik bilgi ve tutumlarının incelenmesi [A research study on gifted students knowledge and attitudes towards environment]. (Unpublished Master's Thesis), Adiyaman University, Institute of Science, Adiyaman.

Gentner, D. \& K.J. Holyoak, 1997. Reasoning and two example-based teaching strategies, annual learning by analogy. American Psycholojist, 52(1), 32-34.

Glynn, S., Law, M., Gibson, N.M., \& Hawkins, C.H. (1996). Teaching Science With Analogies: A Resource for Teachers and Textbook Autors, http://curry.edschool.virginia.edu/go/clic/nrrc/html

Günbatar, S., \& Sarı, M. (2005). Developing models for difficult and abstract concepts in electrics and magnetism. Gazi University Gazi Faculty of Education Journal, 25(1), 185-197.

Güneş, T., Dilek, N. Ş., Demir, E. S., Hoplan, M., \& Çelikoğlu, M. (2010, November). Öğretmenlerin kavram öğretimi, kavram yanılgılarını saptama ve giderme çalışmaları üzerine nitel bir araştırma [A qualitative research on teachers' concept teaching determination and elimination of misconceptions]. In International Conference on New Trends in Education and Their Implications, 11(13), 937-944.

Güven, E. (2014). Metaphoric perception of science and technology teachers and teacher candidates for environmental education. Journal of Research in Education and Teaching, 3(3), 26-37.

Han, M., \& Kim, H.B. (2018). Elementary Students' modelling using analogy models to reveal the hidden mechanism of the human respiratory system. Int J of Sci and Math Educ, 1-20.

Harrison, A. (1992). Evaluation of a model for conceptual change: the use of bridging analogies teaching analogies in secondary science (Master Thesis), http:// adt.curtin.edu.au/ theses/available/ adt-WCU20020826.122106

Hıdır, M., \& Körhasan, N. D. (2018). Examination of the analogies in science textbooks and opinions of science educators about the effective use of analogies. Necatibey Faculty of Education Electronic Journal of Science and Mathematics Education, 12(2), 415453.

Johnson, G.B. (2018). The Living World. USA: McGraw-Hill Education.

Kaptan, F. (1999). Fen Bilgisi Öğretimi [Science Teaching]. İstanbul: M.E.B. Publications. 
Karakaya, F., Ünal, A., Çimen, O., \& Y1lmaz, M. (2018). Investigation of environmental perceptions of gifted students and their peers. Online Science Education Journal, 3(1), 25-32.

MEB (2006). Millî eğitim bakanlığı bilim ve sanat merkezleri yönergesi [Ministry of Education Directive of Science and Art Centers] From: https://orgm.meb.gov.tr/meb_iys_dosyalar/2016_10/07031350_bilsem_yonergesi.pdf Retrieved: 10.05.2019.

Molles, M.C. (2016). Ecology: Concepts and Applications. USA: McGraw-Hill Education.

Odum, P.E., \& Barrett, W.G. (2008). Ekolojinin Temel Illkeleri [Fundementals of Ecology], (Trans.. Ed.: Kani Işık). Ankara: Palme Pub.

Ören, F.Ş., \& Ateş, Ö. (2018). Analoji kullanılarak yapılan mikro öğretim uygulamalarının kavram haritaları yoluyla değerlendirilmesi. Değişen Dünyada Eğitim, (Ed. Serkan Dinçer), Pegem Atıf İndeksi, 369-384.[Evaluation of micro teaching practices using analogy through concept maps. Education in a Changing World, (Ed. Serkan Dinçer), Pegem Citation Index, 369-384.]

Paatz, R., Ryder, J., Schwedes, H., \& Scott, P. (2004). A case study analysing the process of analogy based learning in a teaching unit about simple electric circuits. International Journal of Science Education, 26(9), 1065-1081.

Pittman, K. M. (1999). Student-generated analogies: Another way of knowing?. Journal of Research in Science Teaching: The Official Journal of the National Association for Research in Science Teaching, 36(1), 1-22.

Reece, J.B, Urry, L.A., Cain, M.L., Wasserman, S.A., Minorsky, P.V., \& Jackson, R.B. (2013). Campbell Biyoloji [Campbell Biology], (Trans. Ed.: Gündüz, E., \& İsmail Türkan, İ.). Ankara: Palme Pub.

Renzulli, J. S., \& Reis, S. M. (1985). The schoolwide enrichment model: A comprehensive plan for educational excellence. Mansfield Center, CT: Creative Learning Press.

Ross, P. M., \& Tronson, D. (2004) Towards conceptual understanding: bringing research findings into the lecture theatre in tertiary science teaching. Proceedings of Scholarly Inquiry into Science Teaching and Learning Symposium, 52-57.

Ross, P., Tronson, D., \& Ritchie, R.J. (2005). Modelling photosynthesis to increase conceptual understanding. Journal of Biological Education, 4(2), 84-88.

Russell, P.J., Hertz, P.E., \& McMillan, B. (2011). Biology: The Dynamic Science, Brooks/Cole. USA: Cengage Learning.

Sadava, D., Hillis, M.D., Heller, H.C., \& Berenbaum, M.R. (2014). Yaşam bilimi biyoloji [Life: The Science of Biology], (Trans. Ed.: Gündüz, E., \& İsmail Türkan, İ.). Ankara: Palme Pub.

Simon, E.J., Dickey, J.L., Hogan, K.A., \& Reece, J.B. (2017). Campbell Biyoloji [Campbell Biology], (Trans. Ed.: Gündüz, E., \& İsmail Türkan, İ.), Ankara: Palme Pub.

Smith, M.T., \& Smith, L.R. (2009). Elements of Ecology, International Edition. USA: Pearson Benjamin Cummings.

Şahin, F., \& Levent, F. (2015). Examining the methods and strategies which classroom teachers use in the education of gifted students. The Online Journal Of New Horizons In Education, 5(3), 69-78.

Tatar, N., \& Kuru, M. (2006). The effect of inquiry-based learning approach in science education on academic achivement. Journal of Hacettepe University Education Faculty, 31, 147-158.

Türk Dil Kurumu (TDK) (2011). Türkçe Sözlük (11th Edition). [Turkish Dictionary] Ankara: Turkish Language Institution Publications. 
Walker, J.D., Wassemberg, D., Franta, G., \& Cotner, S. (2017). What determines student acceptance of politically controversial scientific conclusions. Journal of College Science Teaching, 47, 46-56.

Withgott, J. \& Brennan, S. (2008). Environment: The Science Behind The Stories (Third Edition). USA: Pearson Publication.

Yenice, N., Tunç, G. A., \& Yavaşoğlu, N. (2018). High school students' and pre-service science teachers' generated analogy towards biology. Journal of Muğla Sitkı Koçman University Education Faculty, 5(2), 16-30.

Yıldırım, A. \& Şimşek, H. (2011). Sosyal bilimlerde nitel araştırma yöntemleri (8th Edition) [Qualitative research methods in the social science] Ankara: Seçkin Publication. 